\title{
Chemistry and Insecticide activity of Bougainvillea glabra Choisy against Spodoptera frugiperda Smith
}

\author{
Silvia Evangelista-Lozano \\ Lorena Reyes-Vaquero \\ Antonia de Jesús-Sánchez \\ Sandra Victoria Ávila-Reyes \\ *Antonio Ruperto Jiménez-Aparicio \\ Centro de Desarrollo de Productos Bióticos \\ Instituto Politécnico Nacional \\ Carretera Yautepec-Jojutla, Km 6, \\ CEPROBI no. 8, Col. San Isidro \\ Yautepec, Morelos 62731 México \\ María Yolanda Ríos \\ Centro de Investigaciones Químicas IICBA \\ Universidad Autónoma del Estado de Morelos. \\ Av. Universidad no. 1001, Col. Chamilpa \\ Cuernavaca, 62209 México. \\ *Corresponding Author: aaparici@ipn.mx
}

\begin{abstract}
Bougainvillea glabra Choisy var 'Variegata' shows medicinal and insecticidal activities attributed to the chemical content of this botanical variety. The purpose of this work was to identify the metabolites obtained from methanol extracts of leaves of this variety cultivated under greenhouse conditions and determine the biological activity against Spodoptera frugiperda larvae. Secondary metabolites were identified through gas chromatography coupled to mass spectrometry (GC-MS) using ${ }^{13} \mathrm{C}$ and ${ }^{1} \mathrm{H}$ nuclear magnetic resonance. Twentythree compounds were identified and d-pinitolwas the major compound isolated. The biologic effect of d-pinitol against second instar larvae was tested at concentrations of 0, 25, 50, 75 100, and 125 ppm. The major biological effect observed was at a 75 ppm concentration, showing low weight and interruption of pupae formation after 60 days. Only emerging adults were used in the test.
\end{abstract}

Keywords: extracts, secondary metabolites, $d$-pinitol, biological effect, bio-insecticide

\section{Introduction}

Bougainvillea glabra Choisy ('buganvilia') of Nyctaginaceae family (Martínez, 1997) presents diverse varieties such as 'Violet', 'Surprise', 'Golden', 'White' and 'Variegate' which are used as ornamentals and in traditional medicine to treat respiratory diseases, diabetes and stomach acidity (Adebayo et al, 2009; Gupta et al., 2009). For this, Mariajancyrani et al. (2013) isolated a terpenoid soluble in ethyl acetate from the leaves: 3-O-acetyloleanolic acid. Sahu and Saxena (2014) isolated one flavonoid from methanolic extract of bracts and identified quercetin-3O- $\alpha$-L-rhamnopyranosyl-(1-6)- $\beta$-D-glucopyranoside. Also, Hussein (2014) identified five known flavonoids: vitexin, isovitexin, chrysoeriol, apigenin, luteolin and a new flavonoid: luteolin-7-O-[2"-O-(5"'-O-feruloyl)- $\beta$-Dapiofuranosyl]- $\beta$-D-glucopyranoside from the methanolic extract of the leaves. Martinez (1997) reported that in $B$. glaba leaves there are $\beta$-sitosterol, glucose, rhamnose, glycine and aspartic acid, along with compounds such as tannins, flavonoids, saponins, steroids, terpenoids and cardiotonic glycosides. And by using GC-MS Rani et al. 
(2012) identified: phytol, squalene, 3-O-methyl-D-glucose, tetradecanoic acid ethyl ester, 9,12,15Octadecatrienoic acid, hexanedioic acid bis (2-ethylhexyl) ester, 1,2-benzenedicarboxylic acid diisooctylester and vitamin E. Bougainvillea glabra var 'Variegata' is considered valuable because the striking appearance of its leaves which are opaque green color with a white milky outline, short internodes and orange color in three bracts where they embrace the white flowers, which are less striking. The plant could be propagated by a hardwood stake (Evangelista et al., 2005).

In observations carried out on different varieties under nursery conditions, it was observed that not all varieties are attacked by insect pests (Valdés et al, 2004). In addition, there exist reports on the effect of $B$. glabra against the leishmaniosis vector from Egypt; Phleboromus papatasi (Diptera: Psychodidae) since the extract killed $16 \%$ of the females and $24 \%$ of the males and reduced their cycle life the rest of individuals (Kaldas et al, 2014). A similar effect was produced in P. argentipes adults, which is also a leishmaniosis vector (Sharma and Sing, 2008). In cabbage leaves (Brassica oleracea var 'Acephala'), the bougainvillea aqueous extract had dissuasive effects towards $95 \%$ of the eggs of Plutella xylostella (Lepidoptera: Plutelliadae) (Medeiros et al, 2005). With the aqueous extract of bougainvillea bracts at $100 \%$ concentration, $80 \%$ of Shitophilus oryzae weevils died (Coleoptera: Curculionidae) (Kalirajan et al, 2012). Some species of Nyctaginaceae family contain compounds with insecticidal activity as $d$-pinitol (Poongothai and Sripathi, 2013). Chaubal et al. (2005) reported that $d$-pinitol caused $90 \%$ and $100 \%$ mortality in the fourth instar larvae of Aedes aegypti and Culex quinquefasciatus at 500 and 50 ppm respectively, while in Helithis zea it inhibited larvae develop (Reese et al, 1982). In tropical and subtropical America regions one of the principal pests in grasses, legumes and horticultural crops is Spodoptera frugiperda (J. E. Smith) (Lepidoptera: Noctuidae) (García and Tarango, 2009). Because B. glabra is a Nyctaginaceae, it is possible that $d$-pinitol exists in some fractions of the methanolic extract. Currently, there are no reports available about the biological activity of this compound against S. frugiperda as well as not reports of the botanical variety 'Variegata' containing the compound. Therefore, the objectives of this research were to isolate and identify the secondary metabolites from methanol extracts of leaves of B. glabra var 'Variegata' grown in nursey and evaluate its biological effect against the larvae of $S$. frugiperda.

\section{Materials and Methods}

\subsection{Collection of plant material}

Ripe leaves of B. glabra variety 'Variegata' plants, located in CeProBi - IPN $\left(18.4944278^{\circ} \mathrm{N}, 99.0534296^{\circ} \mathrm{W}\right.$; altitude 1064 m.a.s.l.) were collected, rinsed and dried for 24 to $48 \mathrm{~h}$ to obtain the dried weight of material.

\subsection{Extract recuperation from $B$. glabra leaves}

The dried material (270 g dry weight) was extracted by maceration in a 51 flat bottom flask and immersion in methanol for 3 days. Afterward, the dissolvent was filtered and evaporated in a rotary evaporator. The solvent was placed again in a flask for 3 days and the procedure was repeated two more times. The three organic residues were mixed to provide of $36.3 \mathrm{~g}$ of the crude methanolic extract from the B. glabra leaves.

\subsection{Chromatographic separation of the crude methanolic extracts of $B$. glabra leaves}

The methanol extract was fractionated by a gravity column chromatography procedure. $36.3 \mathrm{~g}$ of the extract was adsorbed in $34 \mathrm{~g}$ of flash silica gel and placed in a column previously packed with $30 \mathrm{~cm}$ of clean flash silica gel. The column was eluted with different mobile phases: first hexane: ketone (100:0 to 50:50 v/v), second, ketone (100:0) and finally, methanol (100:0) as gradient of elution. Each fraction was analyzed by High Performance Thin Layer Chromatography (HPTLC) separation performed on a percolated silica gel aluminum plate 60 F254 ( $0.25 \mathrm{~mm}$ thick, Merck, Darmstadt, Germany). The spots in TLC were visualized by UV light (280 and $360 \mathrm{~nm}$ UV lamp) after spraying with $1 \%$ developer solution of $\left(\mathrm{NH}_{4}\right)_{4} \mathrm{Ce}-\left(\mathrm{SO}_{4}\right)_{4} \cdot \mathrm{H}_{2} \mathrm{O}$ in $2 \mathrm{~N} \mathrm{H}_{2} \mathrm{SO}_{4}$, which was heated prior to use.

\subsection{Gas chromatography coupled mass spectrometry (GC-MS)}

The main compounds found were also analyzed using GC-MS (Agilent 6890 System Plus, coupled to Agilent 5973 Network Mass selective detector), which was equipped with a silica capillary column (30 m X $0.25 \mathrm{~mm}$, film thickness $0.25 \mathrm{~mm}$ ). The $\mathrm{GC}$ oven temperature conditions were: 45 to $250{ }^{\circ} \mathrm{C}$ with a gradient temperature of $10{ }^{\circ} \mathrm{C} / \mathrm{min}$. A sample volume of $1.0 \mu \mathrm{L}$ of each fraction at $0.02 \mathrm{~g} / \mathrm{L}$ of concentration was injected. The 
identification of the majority of the chemical compounds was based on the comparison of their index mass fragmentation with authentic compounds of the mass spectra database N-15598 equipment (Falodunet al., 2009).

\section{5. ${ }^{1} \mathrm{H}$ and ${ }^{13} \mathrm{C}$ Nuclear Magnetic Resonance (NMR)}

The NMR spectra were measured on a Varian Mercury NMR spectrometer ( ${ }^{1} \mathrm{H}$ NMR, 200 and $400 \mathrm{MHz} \mathrm{MHz}$; ${ }^{13} \mathrm{C}$ NMR, $50 \mathrm{MHz}$ and $100 \mathrm{MHz}$ ). Chemical shifts, $\delta$, were expressed in ppm units downfield from TMS and coupling constants $J$ in Hertz $(\mathrm{Hz})$. Depending of the solubility of the compounds and groups, deuterated solvents as chloroform, methanol or DMSO were used.

\subsection{Evaluation of the fractions of B. glabra against $S$. frugiperda}

Fall armyworm larvae were obtained from a colony maintained at laboratory conditions of the Department of Entomology, at the Centro de Desarrollo de Productos Bióticos of the Instituto Politécnico Nacional (CEPROBIIPN) Morelos, Mexico. The larvae were maintained in a Precision model 818 incubation chamber at $27 \pm 1{ }^{\circ} \mathrm{C}$, 60-70 \% RH and 12:12 h L:D and reared on a meridic diet (Burton \& Perkins 1987). Second-generation (F2) larvae were used for all experiments with 4 replicates of $n=100$ neonate larvae were used in each treatment.

\subsection{Bioassays to assess the toxicity}

Individual fractions of B. glabra were incorporated into the above meridic diet (Burton y Perkins, 1987) by incorporating the methanol extract and the main compound ( $d$-pinitol in fraction $\mathrm{K}$ ) at six concentrations: 0,25 , $50,75,100$ and $125 \mathrm{ppm}$ in order to evaluate its effect on the development and survival of the $S$. frugiperda larvae. The control diet was prepared with $1 \mathrm{~mL}$ of methanol. Diet ingredients and the fractions were mixed following the protocol of Franco et al. (2006) and the prepared mixture was dispensed at $15 \mathrm{~mL}$ per container into cylindrical plastic containers $(3 \mathrm{~cm}$ high $\times 3.5 \mathrm{~cm}$ diameter). Once the diet had cooled and solidified, one neonate larva was placed in each container with the aid of a fine camel hairbrush. Data were arranged in completely randomized design. Each treatment was performed in 4 replicates with a total of 100 neonate larvae.

Observations were made every seven days considering larval development and mortality, according to Duso et al., (2008), particularly weight (mg) and any visible malformations. The larvae were considered dead when they did not mobilize displace or change position after being pressed down on the abdomen with a dissection needle. The developed adults and larvae were kept in laboratory conditions $\left(27+1{ }^{\circ} \mathrm{C}, 60-70 \% \mathrm{RH}\right.$ and photoperiod $\left.16: 8\right)$. The percent mortality was calculated by means of Abbot's formula (Abbot 1925). The resulting data were subjected to ANOVA and mean comparison (i.e., the mean \pm standard deviation (MSD) at $P=0.5$ were also calculated). Prior to ANOVA, the normality and homoscedasticity of the data was verified by the Shapiro-Wilk and Levene tests, respectively (Sigma Plot v.12.5).

\section{Results and discussion}

\subsection{GC-MS of $B$. glabra methanolic crude extract of leaves}

The methanolic crude extract of leaves $B$. glabra was green dark color with a $13 \%$ of yield recovered. Twentythree compounds were identified by GC-MS from groups A, B, C, E and K (Table 1). From group A, five compounds were identified: squalene, pentacosane, heptacosane, nonaocosane and hentriacontane. From group B: 3-buten-2-one, 4-(2,2,6-trimethyl-7-oxabicyclo [4.1.0] hept-1-yl)-, 2(4H)-benzofuranone, 5,6,7,7a-tetrahydro4,4,7a-trimethyl-, 1,7-Nonadien-4-ol, 4,8-dimethyl- and stigmasta-5,22-dien-3-ol were identified. And from group C there were eight compounds identified: 6, 10, 14-trimehyl-, 2-pentadecanone, palmitic acid methyl ester (palmitic acid),9,12-Octadecadienoic acid (Z,Z)-, methyl ester (linoleic acid, methyl ester; cis-9,cis-12Octadecadienoic acid (linoleic acid), (5E, 9E)- 6,10,14-trimethyl-5,9,13-pentadecatrien-2-one, 2,2-Dimethyl-3(3,7,12,16,20-pentamethyl-3,7,11,15,19-henicosapentaen-1-yl) oxiranand vitamin E. From group E was identified three compounds: linoleic acid, methyl ester, phytol, 3,7,11,15-Tetramethylhexadec-2-en-1-ol. And from group $\mathbf{K}$, three other compounds were identified: 3-O-(3H-methyl)-d-glucose, 4-piperidone, 2,2,6,6-tetramethyl- and 2methoxy-4-vinylphenol.

In-group $\mathbf{K}$ a compound that was confirmed as d-pinitol (3-O-methyl-D-chiro-inositol) was found in greater proportion. This was isolated by TLC and analyzed and identified by ${ }^{1} \mathrm{H}$ and ${ }^{13} \mathrm{C}$ NMR. The chemical shifts by ${ }^{13} \mathrm{C}$ (100 MHz, CD $\left.{ }_{3} \mathrm{OD}\right) \delta 84.85$ (C-1), 74.24 (C-5), 73.71 (C-3), 73.49 (C-6), 72.53 (C-2), 71.97 (C-4), 60.76 (OMe). And for ${ }^{1} \mathrm{H}\left(400 \mathrm{MHz}, \mathrm{CD}_{3} \mathrm{OD}\right) \delta 3,9(\mathrm{~d}, J=2.4 \mathrm{~Hz}, 2 \mathrm{H}, \mathrm{H}-1, \mathrm{H}-6), 3.75(\mathrm{dd}, J=9.6$ and $2.4 \mathrm{~Hz}, 1 \mathrm{H}, \mathrm{H}-2), 3.70$ $(\mathrm{dd}, J=9.6$ and $2.4 \mathrm{~Hz}, 1 \mathrm{H}, \mathrm{H}-5), 3.61$ (s, 3H, OMe), $3.52(\mathrm{dd}, J=11.2$ and $11.2 \mathrm{~Hz}, 1 \mathrm{H}, \mathrm{H}-4), 3.26(\mathrm{dd}, J=9.6$ and $9.6 \mathrm{~Hz}, 1 \mathrm{H}, \mathrm{H}-3$ ). The chemical shifts by ${ }^{1} \mathrm{H}$ and ${ }^{13} \mathrm{C}$ NMR was compared with previous reports (Figure 1 and Table 2). 
Table 1. Compounds identified by GC-MS from B. glabra leaves var 'Variegata'.

\begin{tabular}{|c|c|c|c|c|}
\hline TR & Area GC & Compound IPAC name (number) & {$[\mathbf{m}+/ \mathbf{Z}]$} & Fragmentation \\
\hline 8.29 & 3.05 & 4-piperidone, 2,2,6,6-tetramethyl & 155 & $140,112,98,83,58,42$ \\
\hline 10.65 & 1.74 & 1,7-nonadien-4-ol, 4,8-Dimethyl- & 168 & $109,86,69,43$ \\
\hline 11.19 & 1.25 & 2-Methoxy-4-vinylphenol & 150 & $135,107,77$ \\
\hline 13.47 & 5.19 & $\begin{array}{l}\text { 3-Buten-2-one, 4-(2,2,6-trimethyl-7- } \\
\text { oxabicyclo [4.1.0] hept-1-yl)- }\end{array}$ & 208 & $177,135,123,43$ \\
\hline 14.12 & 5.18 & $\begin{array}{l}\text { 2(4H)-Benzofuranone, 5,6,7,7a-tetrahydro- } \\
\text { 4,4,7a-trimethyl- }\end{array}$ & 180 & $165,152,137,111,67,43$ \\
\hline 16.17 & 84.41 & 3-O-methyl-D-glucose & 194 & $144,116,103,87,73$ \\
\hline 17.40 & 7.26 & $\begin{array}{l}\text { (2E)-3,7,11,15-Tetramethyl-2-hexadecen-1- } \\
\text { ol }\end{array}$ & 278 & $137,123,109,95,82,68,57,43$ \\
\hline 17.46 & 1.17 & 6,10,14-Trimethylpentadecantrien-2-one & 268 & $250,165,124,109,71,58,43$ \\
\hline 18.27 & 7.92 & Palmitic Acid methyl ester & 270 & $227,143,87,74,55,43$ \\
\hline 18.73 & 89.78 & Palmitic Acid & 256 & $\begin{array}{l}213,185,171,157,129,83,73, \\
43\end{array}$ \\
\hline 19.93 & 3.03 & $\begin{array}{l}\text { 9,12-Octadecadienoic } \quad \text { acid } \quad(Z, Z)-\text {, } \\
\text { methylester }\end{array}$ & 294 & $\begin{array}{l}263,150,123,109,95,81,67, \\
41\end{array}$ \\
\hline 20.10 & 1.99 & Phytol & 296 & $278,196,123,71,57,43$ \\
\hline 20.36 & 8.22 & cis-9, cis-12-Octadecadienoic acid & 280 & $\begin{array}{l}264,149,123,109,95,81,67 \\
55,41\end{array}$ \\
\hline 20.46 & 75.28 & $\begin{array}{l}9,12,15 \text {-Octadecatrienoic acid, methyl ester, } \\
(Z, Z, Z) \text { - }\end{array}$ & 292 & $\begin{array}{l}149,135,121,108,95,79,67 \\
55,41\end{array}$ \\
\hline 22.47 & 58.99 & Stigmasta-5,22-dien-3-ol & 414 & $\begin{array}{l}397,369,300,271,255,107,81, \\
69,55,43,18\end{array}$ \\
\hline 22.75 & 0.94 & $\begin{array}{l}\text { (5E,9E)-6,10,14-Trimethyl-5,9,13- } \\
\text { pentadecatrien-2-one }\end{array}$ & 247 & $204,161,135,107,81,69,43$ \\
\hline 24.13 & 2.63 & Pentacosane & 340 & $141,113,99,85,71,57,43$ \\
\hline 26.97 & 5.80 & Heptacosane & 380 & $\begin{array}{l}295,197,169,141,113,99,85 \\
71,57,43\end{array}$ \\
\hline 29.12 & 3.74 & $\begin{array}{l}\text { Oxirane, 2,2-dimethyl-3-(3,7,12,16,20- } \\
\text { pentamethyl-3,7,11,15,19- } \\
\text { heneicosapentaenyl)- }\end{array}$ & 426 & $\begin{array}{l}215,189,147,121,95,81,69, \\
41\end{array}$ \\
\hline 29.50 & 10.15 & Squalene & 410 & $149,137,121,95,81,69$ \\
\hline 31.20 & 35.39 & Nonacosane & 408 & $\begin{array}{l}295,197,169,141,113,99,85 \\
71,57,43\end{array}$ \\
\hline 37.86 & 40.06 & Hentriacontane & 436 & $\begin{array}{l}253,225,295,197,169,141 \\
113,99,85,71,57,43\end{array}$ \\
\hline 39.32 & 60.54 & Vitamin E & 430 & $\begin{array}{l}414,388,358,316,288,274, \\
219,165,121,91,43\end{array}$ \\
\hline
\end{tabular}

$\mathrm{RT}=$ retention time 
Table 2. Data of NMR from $d$-pinitol

\begin{tabular}{|c|c|c|c|c|}
\hline \multirow[b]{2}{*}{ Carbon } & \multicolumn{2}{|c|}{${ }^{13} \mathrm{C}$ NMR $(100 \mathrm{MHz})$} & \multicolumn{2}{|l|}{${ }^{1} \mathrm{H}$ NMR $(400 \mathrm{MHz})$} \\
\hline & $\begin{array}{l}\text { Raya et al, } 2008 \\
\text { in } \mathrm{D}_{2} \mathrm{O}\end{array}$ & $\begin{array}{l}\text { Compound } 41 \text { in } \\
\mathrm{CD}_{3} \mathrm{OD}\end{array}$ & Jawla et al, 2013 in $\mathrm{D}_{2} \mathrm{O}$ & Compound 41 in CD3OD \\
\hline 1 & 85.93 & 84.85 & $3.85(1 \mathrm{H}, \mathrm{m})$ & $3.9(1 \mathrm{H}, \mathrm{d}, J=2.4)$ \\
\hline 5 & 74.32 & 74.24 & $\begin{array}{l}3.61\left(1 \mathrm{H}, \mathrm{dd}, J_{5,4}=9.98\right. \\
\left.J_{5,6}=2.6\right)\end{array}$ & $3.70(1 \mathrm{H}, \mathrm{dd}, J=9.6,2.4)$ \\
\hline 3 & 73.75 & 73.71 & $\begin{array}{l}3.19\left(1 \mathrm{H}, \mathrm{dd}, J_{3,2}=9.90\right. \\
\left.J_{3,4}=9.53\right)\end{array}$ & $3.26(1 \mathrm{H}, \mathrm{dd}, J=9.6,9.6)$ \\
\hline 6 & 73.47 & 73.40 & $3.85(1 \mathrm{H}, \mathrm{m})$ & $3.9(1 \mathrm{H}, \mathrm{d}, J=2.4)$ \\
\hline 2 & 72.56 & 72.53 & $\begin{array}{l}3.66\left(1 \mathrm{H}, \mathrm{dd}, J_{5,4}=9.98\right. \\
\left.J_{2,1}=2.6\right)\end{array}$ & $3.75(1 \mathrm{H}, \mathrm{dd}, J=9.6,2.4)$ \\
\hline 4 & 72.04 & 71.97 & $\begin{array}{l}3.50\left(1 \mathrm{H}, \mathrm{dd}, J_{4,3}=9.53\right. \\
\left.J_{4,5}=9.98\right)\end{array}$ & $\begin{array}{l}3.52(1 \mathrm{H}, \mathrm{dd}, J=11.2, \\
11.2)\end{array}$ \\
\hline $\mathrm{OMe}$ & 60.75 & 60.76 & $3.45(3 \mathrm{H}, \mathrm{s})$ & $3.61(3 \mathrm{H}, \mathrm{s})$ \\
\hline
\end{tabular}

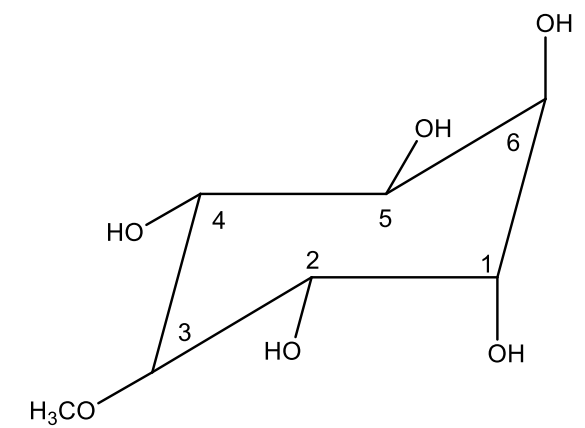

Figure 1.d-pinitol structure, compound identified by ${ }^{13} \mathrm{C}$ and ${ }^{1} \mathrm{H}$ NMR from methanolic leaves extract of $B$. glabravar 'Variegata'

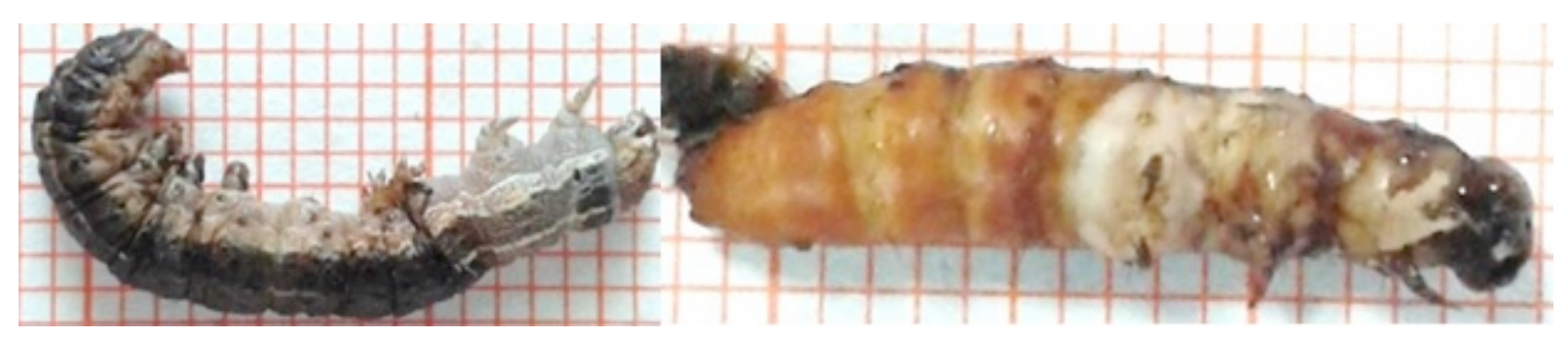

Figure 2. Biological effect of $B$. glabra leaves of var 'Variegata' against $S$. frugiperda, treated with 75 ppm of group K. Larvae showing an incomplete ecdysis (left) and larvae-pupae at intermediate stage (right).

The compounds identified were $30 \%$ of terpenoids type and $22 \%$ of fatty acids. The terpenoids were squalene, oxirane2,2-dimethyl-3-(3,7,12,16,20-pentamethyl-3,7,11,15,19,(2E)-3,7,11,15-tetramethyl-2-hexadecen-1-ol, phytol and 9,12-octadecadienoic acid (Z,Z)-, methyl ester. The compounds alkanes type were hentriacontane, nonacosane, heptacosane and pentacosane. The ketones were 3-buten-2-one, 4-(2,2,6-trimethyl-7oxabicyclo[4.1.0]hept-1-yl)-, 2,2,6,6-tetramethyl-4-piperidone and 6,10,14-trimethyl-5,9,13-pentadecan-2-one, the phenolic compound was 2-methoxy-4-vinylphenol and the lactone type compound was $2(4 H)$-benzofuranone, 5,6,7,7a-tetrahydro-4, 4, 7a-trimethyl.

In the present research, no flavonoids or phenolic acids were isolated, as previously reported from B. glabra. This was probably due to the plant variety, origin of the biological material, the collected zone and the agronomic activities. Only the 3-O-methyl-d-glucose, phytol and vitamin E were previously reported by Rani et al. (2012). Although their compounds were obtained from ethanol extract of B. glabra the plant variety was not reported. Sahu and Saxena (2014), Rani et al. (2012) and Napoleon et al., (2013) experimented with leaves, flowers and 
bracts from India; Hussein (2014) and Kaisoon et al. (2011) studied flowers from Egypt and Thailand, respectively. None of their studies included the leaves or was comparable to the climatic conditions of this present research.

\subsection{Evaluation of the fractions of B. glabra against $S$. frugiperda}

The compound present in the group $\mathbf{K}$ was rich in $d$-pinitol and therefore it was evaluated against $S$. frugiperda at different concentrations from 0 to $125 \mathrm{ppm}$ (Table 3). It could be observed that 50 and $75 \mathrm{ppm}$ produced the best biologic effect at 7 days because the larvae did not gain weight and these treatments $\mathbf{K} 50$ and $\mathbf{K} 75$ ppm were highly statistically different with respect to the control $(\mathrm{p}=0.001)$. In all experiments after 7 and 14 days there were no significant difference among treatments (Kruskal Wallis $\mathrm{H}=55.937$; $\mathrm{df}=10$ and $\mathrm{H}=39.86$, $\mathrm{df}=10$, respectively). In the treatment with $75 \mathrm{ppm}$ of group $\mathrm{K}$, malformations were observed in the larvae after two months and they did not development into pupae. The larvae showed an incomplete ecdysis and $30 \%$ of the population remained in the larvae-pupae intermediate stage (Figure 2).

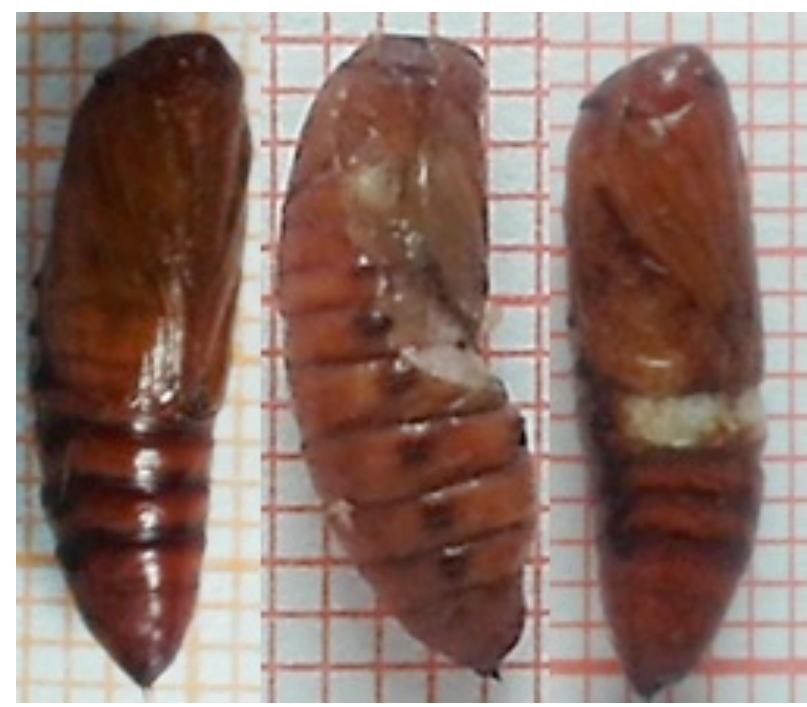

Figure 3. Pupae of S. frugiperdafeed with the group K from B. glabra leaves of var'Variegata'. Normal pupae (left), discontinue cuticle in the ventral segment (middle); and dorsal (right).

In this study, it could be observed an interruption of the growth in the middle phase of the instar larvae into pupae, the insect died at the beginning of the mude without ending its morphogenesis. Some larvae died with the exuviae adhered to the body (Figure 2, left). The $43 \%$ of the pupae that were fed with 25, 100 and 125 ppm showed discontinued cuticle development in the ventral segment, and $39 \%$ of them had ventral ectodermal invaginations growth (Figure 3). The $5 \%$ of the treated with $125 \mathrm{ppm}$, presented exploted bags in the encephalic region. $13 \%$ of pupae appeared normal, however, they did not emerge into the adult stage like the control. The percentage of mortality of $S$. frugiperda larvae that were fed with the K fraction of B. glabravar 'Variegata' was higher than 50 $\%$.

Table 3. Biological activity of group K from B. glabra leaves var 'Variegata' against S. frugiperda on the second instar larvae.

\begin{tabular}{|c|c|c|c|c|c|}
\hline \multirow{2}{*}{$\begin{array}{l}\text { Fractión } \mathrm{K}^{*} \\
\text { ppm }\end{array}$} & \multicolumn{5}{|c|}{$\begin{array}{l}\text { Spodoptera frugiperda weight } \\
(\mathrm{mg})\left(\overline{\mathrm{x}} \pm \mathrm{se}^{* *}\right)\end{array}$} \\
\hline & $\begin{array}{l}\text { Larvae } \\
\text { d7 }\end{array}$ & d14 & $\mathrm{d} 21$ & $\mathrm{~d} 28$ & Pupae \\
\hline 125 & $9.06 \pm 2.99$ & $61.30 \pm 18.80$ & $150.30 \pm 34.70$ & $199.30 \pm 52.10$ & $119.0 \pm 14.8$ \\
\hline 100 & $11.10 \pm 4.67$ & $79.80 \pm 29.10$ & $194.00 \pm 54.20$ & $161.00 \pm 34.80$ & $146.0 \pm 21.6$ \\
\hline 75 & $3.87 \pm 0.82^{\mathrm{a}}$ & $27.90 \pm 5.71^{\mathrm{a}}$ & $97.70 \pm 19.10$ & $156.00 \pm 32.30$ & NFP \\
\hline 50 & $5.32 \pm 1.53^{\mathrm{a}}$ & $36.70 \pm 10.60^{\mathrm{a}}$ & $146.00 \pm 37.80$ & $140.00 \pm 48.00$ & $115.0 \pm 6.4$ \\
\hline 25 & $18.20 \pm 3.93$ & $148.00 \pm 24.80$ & $225.00 \pm 34.80$ & $182.00 \pm 44.90$ & $143.0 \pm 10.5$ \\
\hline 0 & $21.73 \pm 4.28$ & $131.90 \pm 19.98$ & $245.91 \pm 30.7$ & $215.66 \pm 36.89$ & $177.0 \pm 11.1$ \\
\hline
\end{tabular}

${ }^{*}$ Rich in $d$-pinitol; **se $=$ standard error; NFP $=$ No pupae formation 
This is in agreement with Silva et al. (2003) who considered that B. glabra is insecticidal. Also, Chaubal et al. (2005) reported chronic toxicity of $d$-pinitol against $A$. aegypti and $C$. quinquefasciatu. The same alterations as those in our study were observed such as pupae inhibition formation and no emergence of the adults. The processes for the change to the larva stage in insects begin when the epidermis cell responds to the hormonal change through increasing the protein synthesis. For this, the first step comes with the apolysis, which is the separation of the epidermal cells from the inner surface of the old endocuticle and the formation of the subcuticular space, where a molt gel and enzymes are secreted (Marks, 1980).

During molt, the levels of ecdysteroids increase to stimulate the emergence of the apolysis and the synthesis of the cuticle. Later, the levels decrease so that the eclosion hormone (Truman and Riddford, 2002) and the hormone of the activation of the ecdysis (Zitnan et al., 1999) in the final stage are released. The main component of the leaf methanol extract i.e. $d$-pinitol, altered the ecdysteroid metabolism, resulting in an inhibition of emergence or by reducing the ETH liberation (Hésterlee y Morton, 1996). Chaubal et al. (2005) reported that the crude acetone extract of Acacia nilotica showed chronic toxicity against $A$. aegypti and $C$. quinquefasciatus at the $4^{\text {th }}$ instar mosquito larvae at $500 \mathrm{ppm}$, where the active compound identified was $d$-pinitol.

\section{Conclusion}

The main compound identified on B. glabra var 'Variegata' was $d$-pinitol, which is a representative compound of the Leguminosae family. The group K was rich in $d$-pinitol and caused a biological effect against $S$. frugiperda at 75 -ppm concentration by reducing larvae weight and preventing the pupae development. Therefore, $d$-pinitol can be considered a compound with insecticidal activity. This work reported for the first time that this compound isolated from B. glabra var 'Variegata' has potential to control an insect pest.

\section{Acknowledgments}

We are grateful to CONACYT, CEPROBI-IPN (BEIFI, SIBE and COFAA) scholarships and the Universidad Autónoma del Estado de Morelos.

\section{References}

Adebayo GI, Oluwakemi TA, Bamidele VO and Ayodele OS. (2009). Anti-diabetic Properties of the Aqueous Leaf Extract of Bougainvillea glabra (Glory of the Garden) on Alloxan-Induced Diabetic Rats Rec Nat Prod, 3(4):187-192.

Burton LR, and Perkins D. (1987). Rearing the corn earworm and fall armyworm for maize resistance studies. Proceedings of the International Symposium on Methodologies for Developing's Host Plant Resistance to Maize Insects. CIMMYT. México, 35-37

Chaubal R, Pawar VP, Hebbalkar DG, Tungikar BV, Puranik GV, Deshpande HV. And Deshpande RN. (2005). Larvicidal activity of Acacia nilotica extracts and isolation on D-pinitol a bioactive carbohydrate. Chem Biodivers, 2: 684-688.

Duso C, Malagnini V, Pozzebon A, Castagnoli M, Liguori M. and Simoni S. (2008). Comparative toxicity of botanical and reduced risk insecticides to Mediterranean populations of Tetranychus urticae and Phytoseiulus persimilis (Acari etranychidae, Phytoseiidae). Bio Control, 47(1): 16-21.

Evangelista LS, Manzanares CY, Escobar AS, Ventura ZE. (2005). Propagación de tres cultivares de Bougainvillea glabra Choisy mediante esquejes en diferentes sustratos. ISTH, 48:161-163.

Falodun A, Siraj R. and Choudhary MI. (2009). GC-MS Analysis of insecticidal leaf essential oil of Pyrenacantha staudtii Hutch and Dalz (Icacinaceae). Trop J Pharm Res, 8(2): 139-143.

Franco ASL, Jimenez PA, Luna LC. and Figueroa BR. (2006). Efecto tóxico de semillas de cuatro variedades de Carica papaya (Caricaceae) en Spodoptera frugiperda (Lepidoptera: Noctuidae). Folia Entomol Mex, 45: 171-177.

García NG and Tarango RSH. (2009). Manejo biorracional del gusano cogollero del maíz. Folleto técnico 30. INIFAP.

Gupta V, George M, Joseph L, Singhal M. y Singh HP. (2009). Evaluation of Antibacterial Activity of Bougainvillea glabra "Snow White" and Boungainvillea glabra Choisy. J Chem Pharm Res, 1(1): 233237. 
Hésterlee S, and Morton DB. (1996). Insect physiology: the emerging story of ecdysis. Curr. Biol, 6: 648-650. Hussein AA. (2014). New flavone from the aerial parts of Bougainvillea glabra. IJCER4 (10): 2250-3005.

Jawla S, Kumar Y, and Sardar YKM. 2013. Isolation of antidiabetic principle from Bougainvillea spectabilis Willd (Nyctaginaceae) stem bark. Trop J Pharm Res, 12(5): 761-765.

Kaldas R, El Shafey AS, Shehata MG, Samy AM, and Villinski JT. (2014). Experimental effect of feeding on Ricinus communis and Bouganvillea glabra on the development of the sand fly Phlebotomus papatasi (Diptera: Psychodidae) from Egypt. J Egypt Soc Parasitol, 44(1): 1-12.

Kaisoon O, Konczak I. and Siriamornpun S. (2011). Potential health enhancing properties of edible flowers from Thailand.Food Res Int, 46(2): 563-571.

Kalirajan A, Mariselvam R, Savarimuthu MJ, Narayanan KR, Athi NG, and Ranjit SAJA. (2012). Utilization of Bougainvillea glabra for prepared natural colouring agent and biopesticides. Int J Curr Res, 4(9): 009-011.

Mariajancyrani J, Chandramohan G, Saravanan and Elayaraja A. (2013). Isolation and antibacterial activity of terpenoid from Bougainvillea glabra Choisy leaves. Asian J Plant Sci Res, 3(3):70-73.

Marks EP. 1980 Insect tissue culture: an overview, 1971-1978. Annu Rev Entomol, 25: 73-101.

Martínez VEA. (1997). Aislamiento y caracterización de metabolitos secundarios de Bougainvillea glabra, Choisy, (Nictaginácea); Leucophyllum frutescens, (Rerl) I. M. Jonst, (Scrophulariaceae) y Eriobotry a japónica, Linsl (Rosaceae). Tesis de Maestría. Facultad de Ciencias Biológicas. Universidad Autónoma de Nuevo León.

Medeiros CAM, Leal BJrA and Leite TA. (2005). Efeito de extratos aquosos de plantas nã oviposição da tracadas-crucíferas, em couve. Bragantia, 64(2): 227-232.

Napoleon A, Swetha KS, and Angajala G. (2013). In-vitro antioxidant and antibacterial studies of betacyanin isolated from the bracts of Bougainvillea glabra. Int J Pharm Sci, 5(4):84-87.

Poongothai G, and Sripathi SK. (2013). A review on insulinmimetic pinitol from plants. IJPBS, 4(2): 992-1009.

Rani JJM., Chandramohan G, and Renganathan R. (2012). Antioxidant activity, preliminary phytochemical investigation and GC-MS study of Bougainvillea glabra Choisy leaves. Int J Pharm Pharm Sci, 4 (S2):12-16.

Raya GD, Pamatz BT, Del Río TRE, Martínez MRE, Ron EO and Martínez PMM. (2008). D-(+)-Pinitol a component of the heartwood of Enterolobium cyclocarpum (Jacq.) Griseb. Z. Naturforsch 63c: 922-924.

Reese J, Chan GB, and WaissCAJr. (1982). Effects of cotton condensed tannin, maysin (corn) and pinitol (soybeans) on Heliothis zea growth and development. J Chem Ecol, 8(12): 1429-1436.

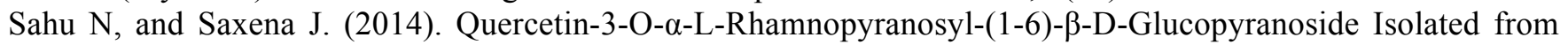
Bougainvillea glabra. IJPRS3 (1):489-491.

Sharma U, and Singh S. (2008). Insects vectors of Leishmania: distribution, physiology and their control. J Vector Borne Dis, 45: 255-272.

Silva G, Lagunes A, and Rodríguez J. (2003). Control de Sitophiluszeamais (Coleoptera: Curculionidae) con polvos vegetales solos y en mezcla con carbonato de calcio en maíz almacenado. Cien. Inv. Agr. 30(3): 153-160.

Truman JW, and Riddiford LM. (2002) Endocrine insights into the evolution of the metamorphosis in insects. Annu Rev Entomol, 47: 467-500.

Valdés ME, Aldana L and Evangelista S. (2004). Presencia de Aphis craccivora Koch (Homoptera:Aphididae) en Bougainvillea glabra Choisy, en el estado de Morelos, México. Folia Entomol Mex, 43(1):167-168.

Zitnan D, Ross LS, Zitnanova I, Hermesmann JL, Gill SS. and Adams ME. (1999). Steroid induction of a peptide hormone gene leads to orchestration of a defined behavioral sequence. Neuron, 23: 523-535. 